\title{
Increasing P-Availability and P-Uptake Using Sugarcane Filter Cake and Rice Husk Ash to Improve Chinesse Cabbage (Brassica Sp) Growth in Andisol, East Java
}

\author{
S. R. Utami ${ }^{1,2}$, S. Kurniawan ${ }^{2}$, B. Situmorang ${ }^{3}$ \& N. D. Rositasari ${ }^{3}$ \\ ${ }^{1}$ Soil and Water Management, Post-Graduate Programme, Faculty of Agriculture, Brawijaya University, Jl. \\ Veteran 1, Malang, Indonesia \\ ${ }^{2}$ Agroecotechnology Study Programme, Faculty of Agriculture, Brawijaya University, Jl. Veteran 1, Malang, \\ Indonesia \\ ${ }^{3}$ Soil Science Study Programme, Department of Soil Science, Faculty of Agriculture, Brawijaya University, Jl. \\ Veteran 1, Malang, Indonesia \\ Corresponce: S. R. Utami, Faculty of Agriculture, Brawijaya University, Jl. Veteran 1, Malang, Indonesia. Tel: \\ 62-341-553-623. E-mail: sriyutami@gmail.com
}

Received: June 13, 2012 Accepted: June 29, 2012 Online Published: August 31, 2012

doi:10.5539/jas.v4n10p153 URL: http://dx.doi.org/10.5539/jas.v4n10p153

\begin{abstract}
The production potential in Andisols is limited by the high P-retention capacity. Farmers commonly use organic matter. Sugarcane filter cake (blothong, Indonesian, SFC) and rice husk ash (RHA) are locally available in Coban Rondo, Malang, East Java and hence potentially used for soil amendment. To study the effects of SFC and RHA on P availability, $\mathrm{P}$ uptake and plant growth (Brassica sp.), soil samples were taken from 0-20 cm depth, incubated with SFC (21.37 Mg.ha ${ }^{-1}$ ) and RHA (44.64 Mg.ha ${ }^{-1}$ ). Total P, P-available, pH, organic carbon, exchangeable cations $(\mathrm{K}, \mathrm{Na}, \mathrm{Ca}, \mathrm{Mg})$, and $\mathrm{P}$ retention curve were determined at $0,15,30$, and 45 days after incubation. Crop parameters (height, number of leaves, total dry weight) and P-uptake were also measured at 2, 4, 6 weeks after planting.

The results showed that RHA was more effective than SFC to decrease P retention and increase P availability ( $120 \%$ on RHA; and $78 \%$ on SFC). Soils having higher organic matter tended to have higher P availability. As a consequence, RHA and SFC increased P-uptake respectively 3 and 2 times in soil rich in organic matter, and 1.9 and 2.7 times in soil low in organic matter compared to untreated soil. Increasing P-uptake was followed by plant growth improvement. RHA was more effective than SFC in soil rich in organic matter, but not soil low in organic matter.
\end{abstract}

Keywords: Andisols, P retention, P-available, P-uptake

\section{Introduction}

Soils developed on volcanic eruption products are reflected by their extremely high crop productivity, and often associated with the high human carrying capacity (Leamy, 1984). On the island of Java, which has a total area of $126000 \mathrm{~km}^{2}$, about one third of the surface or $35,140 \mathrm{~km}^{2}$ is covered by volcanic deposits (Baak, 1949). In the 19th century, where population densities are still relatively low in most areas, the most densely populated area (more than 400 persons $/ \mathrm{km}^{2}$ ) were located in the volcanic ash soil zone of central Java (Mohr, 1938). It is interesting to note that the population density is a function of the nature of the soils, which in turn related to the presence of active volcano.

Soils developed from volcanic ash products, generally classified as Andisols, are agriculturally important in Indonesia, because of their productivity and acreage of food and industrial crop growth. The climate is favorable for growing horticulture crops, but the production is often low. Very low $\mathrm{P}$ availability is a major limiting factor in achieving optimum growth and production. Clay fraction in Andisols is normally allophanic which has a high $\mathrm{P}$ sorption capacity, leading to a low availability of $\mathrm{P}$. In the chemical structure of allophone, there are many free standing - $\mathrm{OH}$ and $\mathrm{OH}_{2}$ groups, resulting in many positive charges in normal $\mathrm{pH}$ range, so have a strong bond to the phosphate complex anion. 
Phosphorus fixation is commonly minimized by liming, adding organic matter, or silicates. Increasing $\mathrm{pH}$ by liming creates negative charge, hence repulsing phosphate anion. Whereas silicate anion is easily adsorbed than phosphate, hence blocking the positive charge. Among the three ameliorants, the most commonly used is organic materials because it is usually cheaper and locally available. The active groups in the organic materials, which are negatively charged, form the chelation with positively charged allophane, releasing $\mathrm{P}$ to the soil solution (Lopez, Siegart \& Rodriguez, 1986). In addition, organic matter may provide nutrients, increase cation exchange capacity, and improve suitable bio-physical condition for plant growth.

Sugarcane filter cake (locally called blothong, SFC) and rice husk ash (locally called abu sekam padi, RHA) are potentially used as organic ameliorant in Andisols. Sugarcane filter cake is a solid waste in sugar purification process. SFC is composed of humus, total $\mathrm{N}, \mathrm{C} / \mathrm{N}, \mathrm{P}_{2} \mathrm{O}_{3}, \mathrm{CaO}$ and $\mathrm{MgO}$, which is quite good as an organic fertilizer (Santoso, 2000). SFC contains 26.51\% C-organic (Santoso, 2009) or 50-70\% organic matter (Mulyadi \& Simoen, 2001). Previous research (Tunggal, Zahab, \& Haryono, 2007) reported growth improvement in corn and mustard by using SFC.

RHA is the outer part of the rice grain, as a by product of milling process. Rice husk is about $20 \%$ of rice weight, and after burning leaves $15 \%$ of weight as a husk ash. Use of RHA to improve plant growth was also reported (Ilyas, Syekhfani \& Prijono, 2000; Martias, Nasution, \& Octriana, 2009). Potassium and phosphorous contents on RHA were $0.01-2.69 \% \mathrm{P}_{2} \mathrm{O}_{5}$ and $0.1-2.54 \% \mathrm{~K}_{2} \mathrm{O}$ respectively and the $\mathrm{pH}$ was 08.1-11.0 (Bronzeoak Ltd, 2003; Priyadharsini \& Seran, 2009). Furthermore, RHA benefit from the low content of Carbon and C/N ratio, and high percentage of Silicium which is believed to release $\mathrm{P}$ from adsorption sites.

The two organic materials (SFC and RHA) were very abundant in Andisols around Malang. In 2008, about 400.000 ton dry rice grain was produced in Malang Regency, from which 12,000 tons RHA was obtained. Whereas Sugar Factory Kebon Agung Malang, produce 21,000 tonnes SFC per annum for one-time process. If the dosage of 20-30 tons filter cake/ ha and 5-10 tons of rice husk ash/ha are used (Santoso, 2000; Ilyas et al., 2000), so they may potentially improve respectively 700-1050 ha and 1200-2400 ha of agricultural land.

Utilization of SFC and RHA is not only an effort to find alternative to inorganic fertilizers, but also to support healthy farming by making use of local potentially available materials. Many previous researches studied the use of SFC and RHA to improve soil physical and chemical properties, only few however examined its function in the release of P adsorbed on Andisol. So it is still necessary to study the effect of SFC and RHA on the P sorption, P-availability in the soil and its impact on P uptake and plant growth (chinnese cabbage).

\section{Materials and Methods}

Soil samples were taken from upper 0-20 cm in Coban Rondo, Pujon, Malang, East Java which is situated at around $1400 \mathrm{~m}$ above sea level. The soils were classified as Typic Hapludand (Soil Taxonomy) or Haplic-Silandic Andosol (Dystric, siltic) in WRB (IUSS Working Group WRB, 2007). Soil sampling was done at 2 different level of organic carbon (soil with low 3\% and high 5.5\% organic C) because amorphous content was expected to increase with the decrease of organic matter content, known as anti-allophanic effect (Van Ranst, Utami, \& Shamsuddin, 2002). SFC and RHA were applied to the soils respectively at 21.37 and 44.64 tons ha $^{-1}$, based on the $50 \%$ P-retention sufficiency.

The research was then conducted in the green house, at the Faculty of Agriculture, Brawijaya University. This study used factorial completely randomized design consisting of two factors and three replications. The first factor was soil organic matter content $\left(A_{1}\right.$ and $A_{2}$, respectively low and high organic carbon content) and the second factor was type of organic material ( $\mathrm{B}_{1}$ and $\mathrm{B}_{2}$, respectively applied with RHA and SFC).

Soil $\mathrm{pH}, \mathrm{P}$-available, organic carbon, exchangeable cations $(\mathrm{K}, \mathrm{Na}, \mathrm{Ca}, \mathrm{Mg})$, and $\mathrm{P}$ retention curve were determined at $0,2,4,6$ weeks after incubation. The soil $\mathrm{pH}$ was measured in $\mathrm{H}_{2} \mathrm{O}$ and $1 \mathrm{M} \mathrm{KCl}$ in a 1:1 soil solution ratio. Organic carbon was determined by Walkey-Black method (Allison, 1965). Exchangeable basic cations (K, $\mathrm{Na}, \mathrm{Ca}, \mathrm{Mg}$ ) were extracted by $\mathrm{NH}_{4} \mathrm{OAc} \mathrm{pH}$. Available phosphorus was measured using Bray-1 method, and P-retention curve was determined using Widyaningsih and Ritchie method (1990a, b, c). Crop parameters (height, number of leaves, total weight) and P-uptake were also measured. The data obtained were statistically tested by $\mathrm{F}$ test level 5\%, then followed by Duncan test, correlation, and regression to determine the relationship between the parameters

\section{Results and Discussions}

\subsection{Potential P Supply of the Oganic Matter}

Chemical composition of SFC and RHA was summarized in Table 1. Compared to RHA, the SFC contained higher amount of organic carbon, total phosphorus, and total $\mathrm{N}$, but lower content of basic cations. This 
suggested that SFC potentially released $\mathrm{P}$ and $\mathrm{N}$ higher, but possibly at lower mineralization rate than RHA. Mineralization rate of organic material can be predicted with a value of $\mathrm{P}$ content and $\mathrm{C} / \mathrm{P}$ organic matter. Phosphorus in organic material will quickly be mineralized or released, making readily available for plants if the levels of P-total in the organic material is more than $0.25 \%$ and the ratio $\mathrm{C} / \mathrm{P}$ is less than 200 . RHA had a higher quality $(1.56 \% \mathrm{C}$ and $\mathrm{C} / \mathrm{P} 2.78)$ than $\mathrm{SFC}(30.28 \% \mathrm{C}$ and $\mathrm{C} / \mathrm{P} 25.88)$, hence it might released $\mathrm{P}$ faster than SFC.

Apart from the $\mathrm{C} / \mathrm{P}$, the content of basic cations in the organic material also determines the release of $\mathrm{P}$-available. A higher content of basic cation has greater ability to increase soil $\mathrm{pH}$ through the release of $\mathrm{OH}^{-}$. As the soil $\mathrm{pH}$ increases, the negative charges increase, and so decrease P adsorbed, hence increases available P (Qofuku \& Sumner, 2002). The content of basic cations in RHA was higher $\left(3.93 \mathrm{cmol} \mathrm{kg}^{-1)}\right.$ than in SFC $\left(1.68 \mathrm{cmol} \mathrm{kg}^{-1}\right)$. In addition, RHA is also rich in silicium, the silicate produced has ability to block positive sites capable of adsorbing P. Therefore, RHA is expected to be more effective than SFC in improving available P in Andisols.

Table 1. Selected chemical components of SFC and RHA

\begin{tabular}{lcc}
\hline \multicolumn{1}{c}{ Components } & Sugarcane filter cake & Rice husk ash \\
\hline Organic C $\left(\mathrm{g} \cdot 100 \mathrm{~g}^{-1}\right)$ & 30.28 & 1.56 \\
Total P $\left(\mathrm{g} .100 \mathrm{~g}^{-1}\right)$ & 1.17 & 0.56 \\
Total N $\left(\mathrm{g} .100 \mathrm{~g}^{-1}\right)$ & 2.27 & 0.42 \\
$\mathrm{C} / \mathrm{P}$ & 25.88 & 2.78 \\
$\mathrm{C} / \mathrm{N}$ & 13.34 & 3.71 \\
$\mathrm{Ca}\left(\mathrm{cmol} . \mathrm{kg}^{-1}\right)$ & 0.74 & 1.25 \\
$\mathrm{Mg}\left(\mathrm{cmol} . \mathrm{kg}^{-1}\right)$ & 0.6 & 1.98 \\
$\mathrm{~K}\left(\mathrm{cmol} . \mathrm{kg}^{-1}\right)$ & 0.03 & 0.34 \\
$\mathrm{Na}\left(\mathrm{cmol} . \mathrm{kg}^{-1}\right)$ & 0.31 & 0.36 \\
\hline
\end{tabular}

\subsection{Phosphorus Sorption Curves}

P sorption curves (Figure 1) before incubation showed that to achieve the optimum P concentration requirement for plant growth $\left(2 \mathrm{mg} \mathrm{kg}^{-1}\right)$ required the addition of $367 \mathrm{mgP} \mathrm{kg}^{-1}$ soil in soil having low organic carbon content $\left(\mathrm{A}_{1}\right)$ and $195 \mathrm{mg} \mathrm{P} \mathrm{kg}^{-1}$ soil in soil having high organic matter $\left(\mathrm{A}_{2}\right)$.

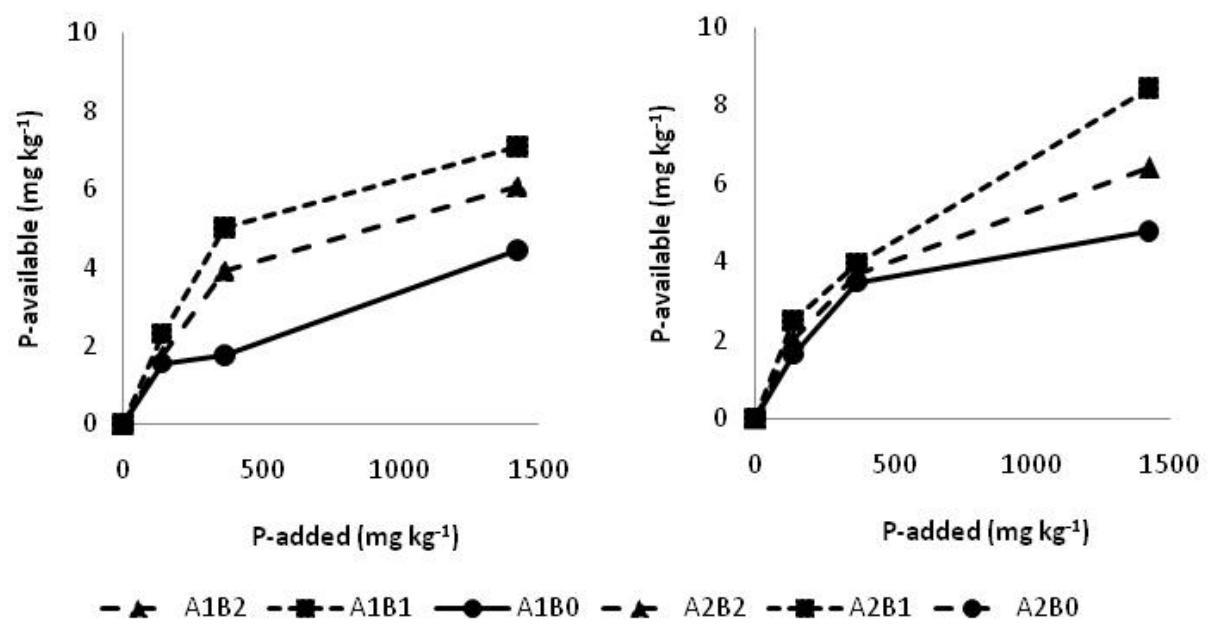

Figure 1. P sorption curve in soils low (left) and high (right) in organic matter after application of rice husk ash $\left(\mathrm{B}_{1}\right)$ and sugarcane filter cake $\left(\mathrm{B}_{2}\right)$

The result suggested that both soils have high retention capacity ( $>99 \%)$, as normally Andisols have very high $\mathrm{P}$ retention capacity. Soil $A_{1}$ (low organic matter content) had higher P retention capacity than $A_{2}$. Andisol with low content of organic matter is normally associated with high allophane content (Van Ranst, Utami, \& Shamshuddin, 
2002), hence has high $\mathrm{P}$ retention capacity. However similar value of $\mathrm{pH} \mathrm{NaF}$ and bulk density in $\mathrm{A}_{1}$ and $\mathrm{A}_{2}$.suggested that allophone content might be unsignificantly different between the two soils. The organic matter tended to lower $\mathrm{P}$ adsorption, probably due to the increasing $\mathrm{P}$ release by the negative sites of organic matter.

SFC and RHA tended to decrease P-adsorbed, hence increase available $\mathrm{P}$ at 30 days after incubation (dai). Compared to control, RHA and SFC increased available P respectively $119 \%$ and $78.21 \%$ higher. This was possibly due to a higher silica and basic cations content in RHA. Silicate complex anion might have blocking effect on the active positive sites of amorphous materials. In addition, higher basic cations in RHA increased $\mathrm{pH}$ and hence increased the negative charge, releasing P into the solution (Utami, Supriyadi, Hairiah, \& Van Noordwijk, 2002). This effect however seemed to be higher in $A_{2}$ than $A_{1}$.

\subsection{Available Phosphorus}

Although unsignificantly different, available $P$ content in $A_{1} B_{0}\left(11.68 \mathrm{mg} \mathrm{kg}^{-1}\right)$ was slightly lower than $\mathrm{A}_{2} \mathrm{~B}_{0}$ $\left(12.68 \mathrm{mg} \mathrm{kg}^{-1}\right)$. RHA and SFC treatment significantly affected available $\mathrm{P}$ in the soil (Figure 2). Compared to control, RHA and SFC increased available P respectively $182 \%$ and $149 \%$ in $\mathrm{A}_{1}$, relatively lower than $267 \%$ and $139 \%$ in $\mathrm{A}_{2}$. A higher organic carbon content in $\mathrm{A}_{2}$ resulted in a more negative charge, which was more repulsive toward phosphate (Utami, Prayogo, Kurniawan, \& Rosalina, 2006; Utami, Kurniawan, Aisyawati, \& Sutikto, 2007). As the negative charges increased in accordance to the increase of organic matter content, organic material application generally increased available $\mathrm{P}$ at the end of the incubation period (45 dai).
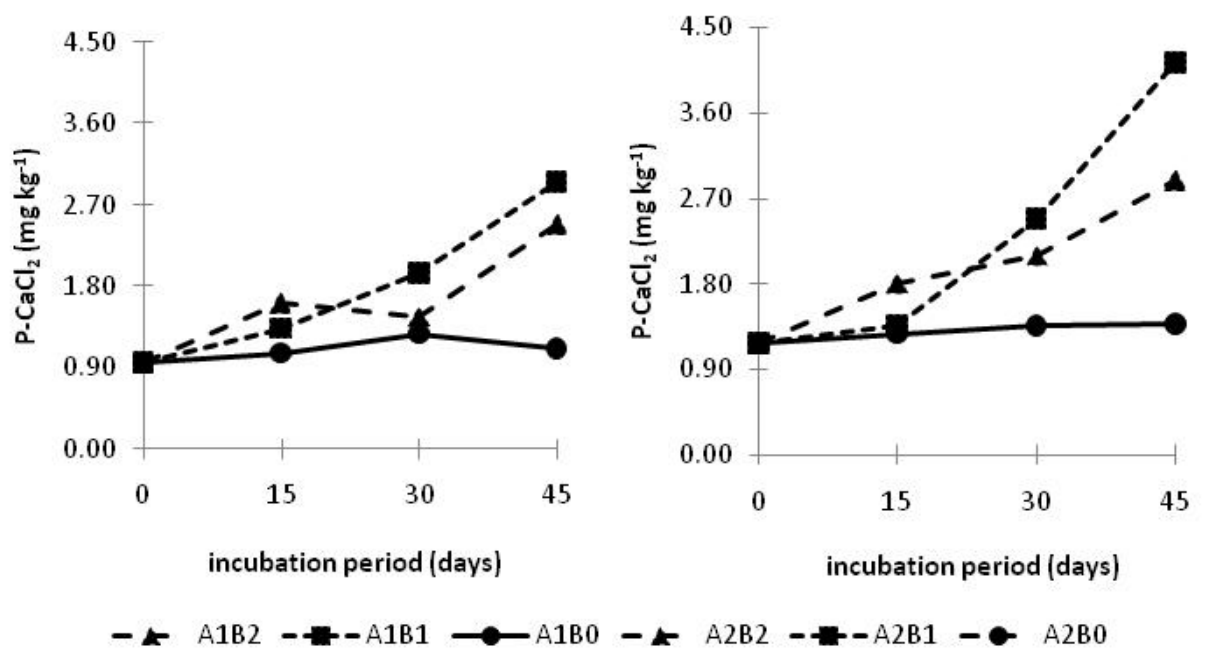

Figure 2. P-available extracted by $\mathrm{CaCl}_{2}$ in sois low (left) and rich (right) in $\mathrm{OM}$, during 45 days incubation with rice husk ash $\left(\mathrm{B}_{1}\right)$ and sugarcane filter cake $\left(\mathrm{B}_{2}\right)$

SFC treatment on $\mathrm{A}_{1}$ however showed a decrease of available $\mathrm{P}$ at $30 \mathrm{dai}$, and increased again after 45 dai. This is due to a lower quality of SFC, hence P mineralization was at slow rate. Phosphorus released at 30 dai was probably lower than $\mathrm{P}$ adsorption, especially in $\mathrm{A}_{1}$ which had a larger sorption capacity. Rossetto, Dias, \& Vitti (2008) recorded that the positive productivity was expected since the use of filter cake, associated with phosphate fertilizer, has been adopted as a practice in some plants, because the presence of organic radicals in the filter cake in decomposition can occupy sites of fixation phosphorus. Other research showed that the combined application of manure and inorganic phosphate fertilizer could improve the availability and efficiency of phosphate, by reducing phosphate adsorption and increasing phosphate solubility in the soils (Tani, Kunimoto, Kato, \& Koike, 2010). Research in Sao Paolo-Brazil showed that SFC application in sugarcane field improved P availability, through the increase of $\mathrm{Ca}$ and decrease of exchangeable Al (Rodella, Silva, \& Filho, 1990).

RHA treatment produced higher available $\mathrm{P}$ content, reflecting a higher capacity to release $\mathrm{P}$. RHA treatment on $\mathrm{A}_{2}\left(\mathrm{~A}_{2} \mathrm{~B}_{1}\right)$ and $\mathrm{SFC}$ treatment on $\mathrm{A}_{1}\left(\mathrm{~A}_{1} \mathrm{~B}_{2}\right)$ showed respectively the highest and the lowest available $\mathrm{P}$ content. The results showed that SFC was less effective in improving available $\mathrm{P}$ in the soil. A decrease in $\mathrm{P}$ sorption was followed by an increase of available $\mathrm{P}$. The available $\mathrm{P}$ was apparently negatively correlated to $\mathrm{P}$ adsorbed, positively correlated to $\mathrm{pH}-\mathrm{H}_{2} \mathrm{O}, \mathrm{pH}-\mathrm{CaCl}_{2}$, organic $\mathrm{C}$, sum of exchangeable basic cations (Table 2).

Table 2. Selected soil properties affecting P sorption 


\begin{tabular}{lcccccc}
\hline Parameters & \multicolumn{5}{c}{ Factors possibly affecting $\mathrm{P}$ availability } \\
\cline { 2 - 7 } & ${\mathrm{P}-\mathrm{CaCl}_{2}}$ & $\mathrm{pH}-\mathrm{CaCl}_{2}$ & $\mathrm{pH}-\mathrm{H}_{2} \mathrm{O}$ & Organic C & $\sum$ basic cations & P uptake \\
\hline P adsorbed & -0.48 & -0.54 & & -0.88 & -0.40 & - \\
$\mathrm{P} \mathrm{CaCl}_{2}$ & - & 0.37 & 0.37 & 0.54 & 0.61 & - \\
$\mathrm{P}-\mathrm{Bray} 1$ & - & - & 0.93 & 0.55 & 0.40 & 0.68 \\
\hline
\end{tabular}

\subsection{Plant P Uptake}

The results showed that SFC and RHA significantly affected ( $\mathrm{p}>5 \%$ ) plant $\mathrm{P}$ uptake (Figure 3). Plant $\mathrm{P}$ uptake at 6 wap (weeks after planting) after RHA treatment in $\mathrm{A}_{2}\left(35.9 \mathrm{mg} \mathrm{kg}^{-1}\right)$ was higher than in $\mathrm{A}_{1}$. There are several possibilities. First, $\mathrm{A}_{2}$ had a higher organic matter content, therefore it potentially released higher $\mathrm{P}$ to the solution, and as a result greater uptake by plant. Second, $\mathrm{A}_{2}$ had more negative sites on organic fractions, hence addition of organic matter would easily released $P$ to the solution. Whereas in $A_{1}$, the addition of organic matter was not sufficient enough to release $\mathrm{P}$ from the fixation sites. Third, high organic matter created better conditions for living microorganisms, which had a positive impact on increasing the uptake of $\mathrm{P}$.
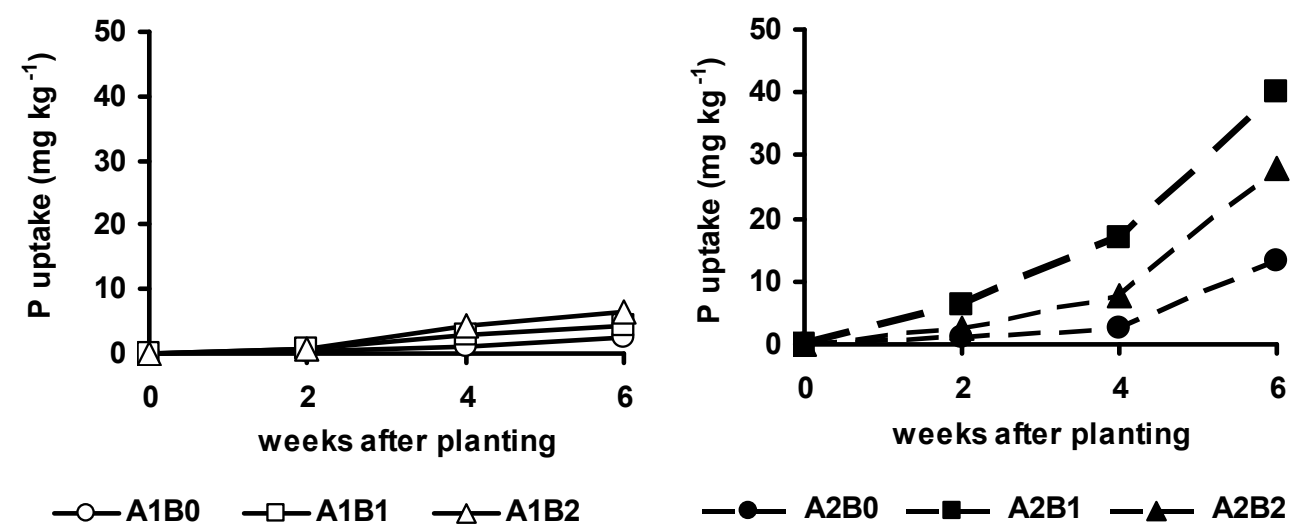

Figure 3. Plant $\mathrm{P}$ uptake during 6 weeks after planting in soils with low (left) and high (right) organic matter content, after application of rice husk ash $\left(\mathrm{B}_{1}\right)$ and sugarcane filter cake $\left(\mathrm{B}_{2}\right)$

Plant $\mathrm{P}$ uptake continued to increase until the end of the planting period and was shown in Figure 2. In $\mathrm{A}_{1}$, the effect of SFC on P uptake was higher (47\%) than RHA. In $\mathrm{A}_{2}$, RHA application resulted a higher P uptake (45\%) than SFC. Plant P uptake was significantly influenced by available P (Table 1) which was higher in RHA. Furthermore, a more basic cations mineralized from RHA will increase soil $\mathrm{pH}$, creating a favorable condition for a better uptake. Minardi, Suntoro, Syekhfani, \& Handayanto (2007) showed that organic matter application might increase the ability of roots to produce phosphatase enzymes which play an important role in the extraction of P.

\subsection{Effect on Plant Growth and Yield}

The results showed that plant height at 6 wap were significantly affected ( $>5 \%$ ) by SFC and RHA treatments (Table 3). In accordance to plant $P$ uptake, plant height was $60 \%$ higher in $A_{1} B_{2}$ than $A_{1} B_{1}$, but $4 \%$ higher in $A_{2} B_{1}$ than $\mathrm{A}_{2} \mathrm{~B}_{2}$. This showed that SFC and RHA application was more effective in respectively $A_{1}$ and $A_{2}$. If we compared $A_{1}$ and $A_{2}$, organic matter application gave more impact to $A_{2}$ than $A_{1}$. This was reflected by plant height at 6 wap which was higher in $\mathrm{A}_{2}$ (2-3.3x) than in $\mathrm{A}_{1}$ (1.1-1.3x) compared to control. RHA and SFC also significantly affected biomass dry weight at 6 wap. Similar trend could be drawn: the effect of SFC and RHA was higher respectively in $\mathrm{A}_{1}\left(4 \mathrm{x}\right.$ higher in $\left.\mathrm{A}_{1} \mathrm{~B}_{2}\right)$ and in $\mathrm{A}_{2}\left(1.33 \mathrm{x}\right.$ higher in $\left.\mathrm{A}_{2} \mathrm{~B}_{1}\right)$, both however were considered more effective in $\mathrm{A}_{2}$ (5-20x) than $\mathrm{A} 1$ (1.2-1.6x) compared to control. This indicated that organic matter application has positive impact on soils having rather high organic matter content. Less effect was shown if organic matter applied on soils which were low in organic matter, possibly high in allophane which had high P retention capacity. Many researchs showed that SFC and RHA application may increase plant growth and crop yield. Priyadharsini \& Seran (2009) showed that application of rice husk ash at the rate of 4.5 tons/ha increased cowpea yield up to 1.44 tons/ha. Similar result was obtained in sugarcane (Santos, Tiritan, \& Foloni, 2010). The increasing yield after filtercake application was due to the replacement of phosporus in fixation sites by organic radicals produced 
during filtercake decomposition (Rosetto, Dias, \& Vitti, 2008). Okon, Ogeh, \& Amalu (2005) also stated that rice husk ash application in combination with urea could sustain rapid growth and better yield of okra faster than NPK fertilizer, because rice husk ash contained almost all other essential plant nutrients and the presence of nitrogen will boost their uptake.

Table 3. Selected crop growth parameters at 6 weeks after planting

\begin{tabular}{lcccc}
\hline \multirow{2}{*}{ Treatments } & \multicolumn{2}{c}{ Weight $(\mathrm{g})$} & $\sum$ leaves & Height $(\mathrm{cm})$ \\
\cline { 2 - 4 } & Fresh & Dry & & \\
\hline A1B0 & $1.28 \mathrm{a}$ & $0.12 \mathrm{a}$ & $6 \mathrm{a}$ & $7.5 \mathrm{a}$ \\
A1B1 & $7.07 \mathrm{a}$ & $0.73 \mathrm{a}$ & $7 \mathrm{a}$ & $15.5 \mathrm{~b}$ \\
A1B2 & $24.59 \mathrm{~b}$ & $2.44 \mathrm{~b}$ & $8 \mathrm{ab}$ & $24.83 \mathrm{c}$ \\
A2B0 & $42.48 \mathrm{c}$ & $5.00 \mathrm{c}$ & $10 \mathrm{bc}$ & $26.66 \mathrm{c}$ \\
A2B1 & $98.06 \mathrm{e}$ & $8.03 \mathrm{~d}$ & $12 \mathrm{~d}$ & $31.16 \mathrm{~d}$ \\
A2B2 & $68.36 \mathrm{~d}$ & $6.06 \mathrm{c}$ & $11 \mathrm{~cd}$ & $29.83 \mathrm{~d}$ \\
\hline
\end{tabular}

Note: $\mathrm{A}_{1}$ and $\mathrm{A}_{2}$ : soil with respectively low and high organic carbon content; $\mathrm{B}_{0}$ : untreated; $\mathrm{B}_{1}$ and $\mathrm{B}_{2}$ : respectively rice husk ash and sugarcane filter cake added soils. Similar letters following the numbers indicated unsignificant difference at $\mathrm{p}<0.05$

Increasing growth rate from 4 to 6 wap in $A_{1}$ was relatively higher than $A_{2}$. This results suggested that 1) $P$ bonding agent in $A_{1}$ was stronger than $A_{2} ; 2$ ) the soil had not reached maximum $P$ retention capacity, hence any addition of organic matter was not sufficient enough to release $\mathrm{P} ; 3)$ there was gradual desorption of $\mathrm{P}$ which was faster in $\mathrm{A} 2$ (high OC content) at earlier stage, but faster in A1 (low OC content) at later stage (4-6 wap).

Plant height, number of leaves, biomass dry weight was closely related to P uptake, which in turn determined by available P (Figure 4) and P retention capacity. The organic matter application increased pH, exchangeable basic cations, negative charges, and hence reduced $\mathrm{P}$ retention and increased available $\mathrm{P}$. These combined factors would increase plant growth and yield. Similar research using filtercake in Brazil (Santos, Tiritan, \& Foloni, 2010) showed that the positive effect of filter cake on yield can be attributed to the increased supply of organic matter, phosphorus, calcium, and other nutrients. Filtercake was also reported provided protection against phosphate reactions with clay mineral and iron oxides, which in this research could be allophanic materials.
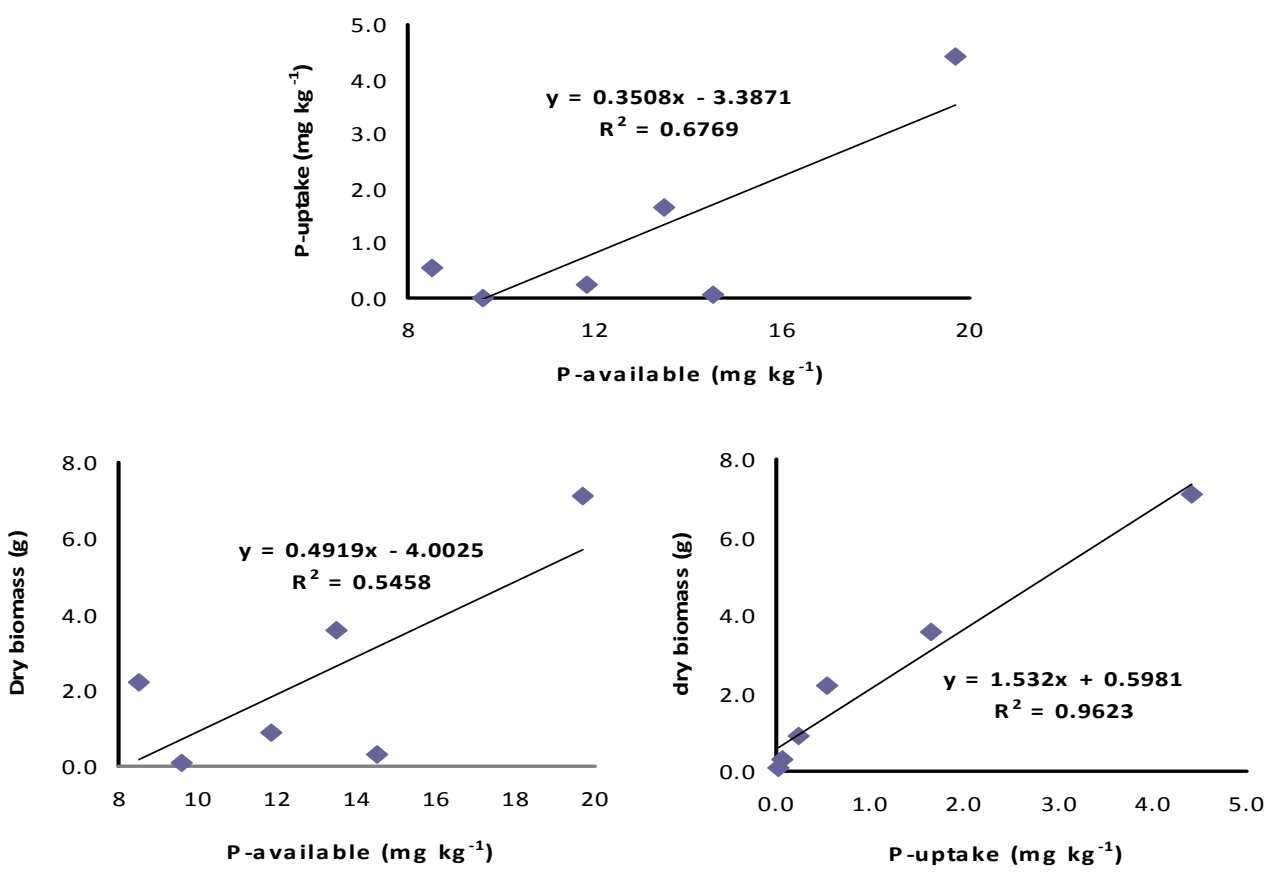

Figure 4. Relationship between biomass, $\mathrm{P}$ uptake, and available $\mathrm{P}$ 


\section{Conclusions}

The results showed that RHA was more effective than SFC to decrease $\mathrm{P}$ retention and increase $\mathrm{P}$ availability ( $120 \%$ on RHA; and $78 \%$ on SFC). This was probably due to a higher content of Si and exchangeable basic cations, which resulted in a higher $\mathrm{pH}$, creating more negative charges which repulse phosphate anion complex.

Soils having higher organic matter tended to have higher P availability. As a consequence, RHA and SFC increased P-uptake respectively 3 and 2 times in soil rich in organic matter, and 1,9 and 2,7 times in soil low in organic matter compared to untreated soil. Increasing P-uptake was followed by plant growth improvement. RHA was more effective than SFC in soil rich in organic matter, but not soil low in organic matter.

\section{References}

Allison, L. A. (1965). Organic matter by Walkley-Black Method. In C.A. Black Soil Analysis Part II. Am Soc. Agron. Madison.

Baak, J. A. (1949). A comparative study on recent ashes of Java volcanoes: Semeru, Kelud and Merapi. Meded. Alg. Prosg. Sta. Bogor (Indonesia), 83, 37.

Bronzeoak Ltd. (2003). Report of the rice husk ash market study. Bronzeoak Ltd, UK, pp. 62.

Ilyas, Syekhfani, \& Prijono, S. (2000). Studying application of agriculture waste (rice husk ash) as silicate source on Andisols and Oxisols to release P adsorbed using ${ }^{32} P$. Risalah Pertemuan Ilmiah Penelitian dan Pengembangan Teknologi Isotop dan Radiasi. (in Indonesian)

IUSS Working Group WRB. (2007). World Reference Base for Soil Resources. World Soil Resources Reports No. 103. FAO, Rome.

Leamy, M. L (1984). Andisol of the World. Congreso International De Suelos Volcanos. Univ. De Laguna Serie Informes No. 13, 164-192.

Lopez, H., Siegart, D. G., \& Rodriguez, J. V. (1986). Competitive Adsorption of Phosphate with Malate and Oxalate by Tropical Soil. Soil Sci. Am. J., 50, 1460-1462. http://dx.doi.org/10.2136/sssaj1986.03615995005000060016x

Martias, F. N., \& Octriana, L. (2009). Using rice husk ash as growing media for durian seedling. Agrivita 31 (3): 259-265. (in Indonesian)

Minardi, S., Suntoro, S., \& Handayanto, E. (2007). Contribution of humic and fulvic acids from organic matter to release P adsorbed in Andisol. Agrivita, 29(1), 37-44. (in Indonesian)

Mohr, E. J. C. (1938). The relation between soil and population density in the Netherland Indies. Amsterdam Tome Deuxiem Section III. 478-493.

Mulyadi, M., \& Simoen, S. (2001). The use of natural rock phosphate and Blotong for sugarcane in Tropaquepts Pasuruan. Berita P3GI (30), 42-48. (in Indonesian)

Okon, P. B., Ogeh, J. S., \& Amalu, U. C. (2005). Effect of Rice Husk Ash and Phosphorus on Some Properties of Acid Sands and Yield of Okra. Communications in Soil Science and Plant Analysis, 36(7), 833-845. http://dx.doi.org/10.1081/CSS-200049460

Priyadharsini, J., \& Seran, T. H. (2009). Paddy Husk Ash as a Source of Potassium for Growth and Yield of Cowpea (Vigna unguiculata L). The Journal of Agricultural Sciences, 4(2), 1-12.

Qafoku, N. P., \& Sumner, M. E. (2002). Adsorption and desorption of indifferent ions in variable charge subsoils: The possible effect of particle interactions on the counter-ion charge density. Soil Sci. Soc. Amer. J., 66(4), 1231-1239. http://dx.doi.org/10.2136/sssaj2002.1231

Rossetto, R, Dias, F. L. F., \& Vitti, A. C. (2008). Problemas nutricionais dos solos nas novas fronteiras canavieiras. Revista Idea News, 94, 78-90.

Rodella, A. A, Silva, L. C. F. da, \& Filho, J. O. (1990). Effects of filtercake application on sugarcane yields. Journal of Turrialba, 40(3), 323-326.

Santoso, B. E. (2000). Waste products of sugar factory: management, prevention and usage for implementation of blue sky and green earth programme. P3GI, Pasuruan, Indonesia. (in Indonesian).

Santos, D. H, Tiritan, C. S., \& Foloni, J. S. S. (2010). Phosphorus fertilization in the plantation of sugarcane with filter cake enriched with soluble phosphate. http: //www.ramiran.net/ramiran2010/docs/Ramiran2010_0096_final.pdf 
Tani, M., Kunimoto, M., Kato, T., \& Koike, M. (2010). Effect of Organic Ligand on Phosphate Adsorption and Availability in Andisol of Eastern Hokkaido, Japan. $19^{\text {th }}$ World Conggres of Soil Science "Soil Solution for a Changing World". August 1-6, 2010. Brisbane, Australia.

Tunggal, D. C., Zahab, R., \& Haryono, N. (2005). Effect of Blotong on growth and water effciency use of chinnesse cabbage (Brassica juncea L.). Jurnal Ilmu Tanah dan Lingkungan, 5(2), 27-37. (in Indonesian)

Utami, S. R., Supriyadi, H. K., \& Van Noordwijk, M. (2002). Using insitu organic matter (Tithonia diversifola dan Tephrosia candida) to improve P availability in Andisol. Agroteksos, 12(3), 196-201. (in Indonesian)

Utami, S. R., Kurniawan, S., Aisyawati, L., \& Sutikto, B. B. (2007). Predicting $\mathrm{pH}_{0}$ and CEC on Coban Rondo Andisol as impact of crop residue and chicken manure application. Agrivita, 29(1), 10-18. (in Indonesian)

Utami, S. R., Prayogo, C., Kurniawan, S., \& Rosalina, P. K. (2006). Impact of crop residue and chicken manure on $\mathrm{P}$ availability in Coban Rondo Andisol, Malang. Habitat, 17(3), 175-186. (in Indonesian)

Van Ranst, E., Utami, S. R. \& Shamshuddin, J. (2002). Andisols on volcanic ash from Java island, Indonesia: Physico-chemical properties and classification. Soil Science, $167(1), \quad 68-79$. http://dx.doi.org/10.1097/00010694-200201000-00007

Widyaningsih, J., \& Rithcie, G. S. P. (1990a). The Ability of Soil Test to Detect Change in Phosporus Absorption and Desorption. Dept. of Soil Sci. and Plant Nutrition School of Agriculture. University of Western, Australia.

Widyaningsih, J., \& Rithcie, G. S. P. (1990b). Prediction of the Phosporus Requirement for Some Soils from East Java Indonesia. Dept.of Soil Sci. and Plant Nutrition School of Agriculture. University of Western, Australia.

Widyaningsih, J., \& Rithcie, G. S. P. (1990c). Estimating Ionic Strength of the Soil Solution and the Determination of pH of Some Soils from East Java Indonesia. Dept. of Soil Sci. and Plant Nutrition School of Agriculture. University of Western, Australia. 